\title{
Energy expenditure on household, childcare and occupational activities of women from urban poor households
}

\author{
T. Sujatha, Veena Shatrugna*, Y. Venkataramana and Nazeema Begum \\ Clinical Division, National Institute of Nutrition, Indian Council of Medical Research, \\ Jamai-Osmania PO Hyderabad-500 007, India
}

(Received 21 August 1998 - Revised 14 April 1999 - Accepted 17 August 1999)

\begin{abstract}
This present study attempts to measure the energy cost of activities of women from the poor socio-economic group in India. Women in the age group of 18-40 years ( $n$ 98) either working for incomes or classified as homemakers were randomly selected. Time disposition studies were conducted by a $24 \mathrm{~h}$ observation of their activities on a typical day. Predominant activities were identified from the activity profiles and standardized for posture and duration. The BMR (Douglas bag method) and energy cost of the activities (Kofranyi-Michaelis meter) were measured by indirect calorimetry. The energy consumption during these activities ranged from $2.94-12.51 \mathrm{~kJ} / \mathrm{min}$. The tasks were divided into standard, household, childcare, occupational and other activities. Using the World Health Organization/Food and Agriculture Organization/United Nations University (1985) criteria, attempts were made to categorize the activities into light, moderate and heavy. It was significant that except for walking, the standard activities and occupational work could be classified into the light category $(<2 \cdot 2 \mathrm{BMR})$. Most of the household and childcare activities except cooking were classified into the moderate to heavy $(2 \cdot 2->2 \cdot 8 \mathrm{BMR})$. The energy expenditure of activities did not differ significantly between women with different occupations. This present study provides an important database on energy costs of activities for computing energy requirements of women involved in similar activity patterns.
\end{abstract}

Energy expenditure: Energy cost of activities: Activity profile

It has been recognized that energy requirement scales must be based on the energy expenditure patterns of populations (World Health Organization/Food and Agriculture Organization/United Nations University, 1985; Indian Council of Medical Research, 1989). There are a large number of studies from the Western world and some developing countries on the energy expenditure patterns of both men and women belonging to different occupational groups (Passmore \& Durnin, 1955; Food and Agriculture Organization/World Health Organization, 1973; Deguzman et al. 1974; Montgomery \& Johnson, 1977; Benjamin et al. 1982). The studies from India have provided data on BMR of subjects of different ages and from different physiological groups, both from the undernourished population and normal subjects (Venkatachalam et al. 1954; Gopalan et al. 1955; Banerjee, 1962; Dakshayani et al. 1962; Khan \& Belvady, 1973; Shetty, 1984; McNeill et al. 1987). Dakshayani \& Ramanamurthi (1962) from the National Institute of Nutrition, Hyderabad, India investigated the energy expenditure of men working as stone-cutters and agricultural labourers. In the case of women, BMR and activity profiles of rural agricultural labourers, both pregnant and non-pregnant, have also been reported (Durnin et al. 1990; Damayanthi,
1995). However, the energy cost of occupational and household activities have not been measured.

Simultaneously, studies on women in India have helped in the understanding of the time-use patterns and the double work burden of women from different urban and rural backgrounds (Batliwala, 1985; Jeffery et al. 1989; Shatrugna et al. 1993). However, the energy equivalents of the different activities were again not measured; but using the factorial method, Batliwala (1985) highlighted the high energy cost of fuel, fodder and water collection, which are generally women's activities. There is a dearth of information from India and other underdeveloped countries on the actual energy costs of women's activities, both occupational and household. Therefore, the total energy requirements of women have been largely computed using the factorial method, based on Western reports (World Health Organization/Food and Agriculture Organization/United Nations University, 1985; Indian Council of Medical Research, 1989). It is known that conditions of work in the Western world, due to mechanization and access to processed foods, are not comparable with the patterns of work of women in a poor socio-economic group in the underdeveloped world. The present study was therefore undertaken to describe and

\footnotetext{
* Corresponding author: Dr Veena Shatrugna, Fax +91 40701 9074, email icmrnin@ren.nic.in
} 
measure the energy costs of some of the major activities of women.

\section{Materials and methods}

\section{Study area}

This present study was carried out in a large urban slum called Addagutta, located in the busiest part of Hyderabad, the capital city of the region of Andhra Pradesh, India. The total population of the slum was $>25000$. The residents belonged to a poor socio-economic group and had migrated to this area in the 1970s, and worked mostly in the unorganized sector. Men were largely rickshaw pullers, autodrivers, vegetable vendors, construction workers, salesmen, railway gangmen etc. Most of the women were daily-wage earners, or home-based workers like vegetable vendors, beedimakers, small shop vendors, tailors etc. A large number were homemakers.

\section{Study group}

A careful census of all the households was carried out for another study (Shatrugna et al. 1993). Women involved in home-based occupations and those who worked for incomes were enumerated and others who did not earn incomes (homemakers) were also identified. For the purposes of the study, sixty-six women involved in home-based occupations like beedi-making ( $n$ 36) and tailoring ( $n$ 30) and thirty-two women who were homemakers were randomly selected. Informed and written consent was obtained from each of the subjects. The study had received the prior approval of the Ethics Committee of National Institute of Nutrition, Hyderabad, India. Details of subjects' ages, marital status and family sizes were collected. Anthropometric measurements including height and weight were measured using standard procedures.

\section{Activity patterns}

Two teams of trained investigators recorded the various activities of the selected women by observing them during the waking hours on a typical day. The predominant activities were identified for purposes of measurement of the energy equivalents.

\section{Measurement of basal metabolic rate}

The subjects were informed about the experiment $1 \mathrm{~d}$ before the measurement. They were collected from their homes at 05.00 hours and transported to the laboratory $1.5 \mathrm{~km}$ away, without causing discomfort of any kind. On arrival, they were asked to rest on a bed in a well-ventilated room for at least $1 \mathrm{~h}$.

Before the start of the experiment, the subject was familiarized with the noseclip, the mouth piece and the other apparatus in the room. The expired air was collected from the subject by the Douglas bag method (Douglas, 1911). These are vinyl bags of 100 litre capacity. A large-calibre flexible rubber hose $0.5 \mathrm{~m}$ in length emerged from the top of the bag and was fixed to a wide bore heavy three-way stop cock. The stop cock was connected via a length of corrugated tubing to a respiratory valve system (Hans Rudolf,
Kansas City, KA, USA), which was attached to a mouth piece. Before the start of the experiment, the residual air in the bags was completely removed. The mouth piece was placed between the lips and the teeth of the subject, the noseclip fixed, and the subject breathed only through the mouth. The corrugated tube was then linked to the Douglas bag. The three-way stop cock was opened to let in the expired air, after which the subject was acclimatized and the pulse rate stabilized. The expired air sample was then collected for 10 min while the pulse rate was monitored at 3 min intervals. The volume of the collected expired air was measured by passing it through a Drygas meter (American Metre Division model DTM-325, Singer, USA). The temperature of the gas and the barometric pressure were also recorded for making the necessary adjustments of volumes to standard temperature and pressure (dry). A small sample of the expired air was collected separately in a rubber bladder for $\mathrm{O}_{2}$ analysis using a paramagnetic $\mathrm{O}_{2}$ analyser (Type OA-272, Sybron Corp., Servomex International Limited, Crowborough, East Sussex, UK).

The analyser was calibrated using $\mathrm{O}_{2}$-free $\mathrm{N}_{2}$ (IOLAR, Indian Oxygen Ltd, Madras, India), atmospheric air and a standard gas mixture. The net discrepancies were within $\pm 0.6 \%$ during the period of study. BMR was calculated using Weir's formula (1949):

$$
\operatorname{BMR}(\mathrm{kJ} / \mathrm{min})=\mathrm{VE} \times \mathrm{O}_{2} \times 5 / 0 \cdot 239,
$$

where $\mathrm{VE}$ is the expired air volume/min corrected to standard temperature and pressure (dry) and $\mathrm{O}_{2}$ is the (expired - inspired) $\mathrm{O}_{2}$ concentration/100.

\section{Measurements of the energy cost of activities}

For the purposes of carrying out measurements based on the observations, the details of each of the typical activities, such as postures, durations etc. were determined. Descriptions of typical activities for which measurements were obtained are listed in the Appendix. The energy costs of these activities were measured by open-circuit indirect calorimetry. The expired air sample from the subject performing each activity was collected in a rubber bladder using a Kofranyi-Michaelis respirometer (Viteri et al. 1971). The $\mathrm{O}_{2}$ content of the expired air was analysed by using a Servomex $\mathrm{O}_{2}$ analyser (Sybron Corp.). In all the measurements, a $3 \mathrm{~min}$ acclimatization period preceded the actual collection of expired air and the time over which the sample was collected varied from 4-10 min, except cooking, for which the duration was 15-20 min. Measurement of an activity was carried out only if it had been identified during the day of observation.

\section{Statistical methods}

Mean values and standard deviations are shown. CV were calculated for energy cost values. Significance of differences between means was calculated by ANOVA.

\section{Results}

The mean age and family size of the study group were $29 \cdot 0$ (SD 5.58) years and 5.1 (SD 1.09) persons respectively and 
Table 1. Anthropometric measurements of women of different occupations (Mean values and standard deviations)

\begin{tabular}{|c|c|c|c|c|c|c|c|c|}
\hline & \multicolumn{2}{|c|}{ Homemakers } & \multicolumn{2}{|c|}{ Beedi-makers } & \multicolumn{2}{|c|}{ Tailors } & \multicolumn{2}{|c|}{ Overall } \\
\hline & Mean & SD & Mean & SD & Mean & SD & Mean & SD \\
\hline$n$ & \multicolumn{2}{|c|}{32} & \multicolumn{2}{|c|}{36} & \multicolumn{2}{|c|}{30} & \multicolumn{2}{|c|}{98} \\
\hline Height (m) & 1.490 & 0.0510 & 1.500 & 0.0670 & 1.520 & 0.0620 & 1.504 & 0.0608 \\
\hline Weight $(\mathrm{kg})$ & $42 \cdot 0^{\mathrm{a}}$ & 7.25 & $42 \cdot 7^{\mathrm{a}}$ & 7.99 & $47.0^{\mathrm{b}}$ & 8.60 & 43.6 & 8.14 \\
\hline
\end{tabular}

${ }^{a, b}$ Mean values within a row with unlike superscripts were significantly different.

they were not different in the three occupational groups. Table 1 presents anthropometric measurements of women belonging to three occupations.

The overall mean height was 1.504 (SD 0.0608) $\mathrm{m}$ and mean weight of the group was $43 \cdot 6$ (SD 8.14) kg. Although there were no differences in the heights across the occupations, women tailors had a higher body weight 47.0 (SD $8.60) \mathrm{kg}$ when compared with the beedi-makers and homemakers (42.7 (SD 7.99) $\mathrm{kg} v .42 .0($ SD 7.25) $\mathrm{kg}(P<0.05)$.

Table 2 provides a list of seventeen activities grouped into the following categories: standard, household, childcare and occupational activities. The mean energy equivalents of these activities expressed as $\mathrm{kJ} / \mathrm{min}, \mathrm{kJ} / \mathrm{kg}$ body weight per min. Range and CV are also indicated. The mean energy costs of these activities ranged from 2.94 to $12.51 \mathrm{~kJ} / \mathrm{min}$ $(0 \cdot 066-0 \cdot 288 \mathrm{~kJ} / \mathrm{kg}$ per $\mathrm{min})$.

Standard activities such as lying, sitting and standing consumed the least amount of energy among the whole range of activities $(2.94-3.43 \mathrm{~kJ} / \mathrm{min})$. It was noteworthy that except for cooking, all of the household activities and two of the childcare activities required more than $7.90 \mathrm{~kJ} /$ min. The occupational activities carried out in a sitting posture consumed less energy than most of the household and childcare activities. The values expressed in terms of $\mathrm{kJ} / \mathrm{kg}$ per min followed the same trend. The CV was $12-24 \%$ (mean CV 20\%). Excluding bathing the child, the number of women who participated in the other childcare activities was less than twenty-seven. The mean age and weight of the children were 24 (SD 14) months and 8.66 (SD 1.32) kg. It was surprising that standing holding the child consumed less energy than sitting with the child in the present study $(4.56 v .5 \cdot 31 \mathrm{~kJ} / \mathrm{min})$. The reasons for this are stated in the description given in the Appendix: the child was usually playful and active when it sat on the mother's lap during the

Table 2. List of activities identified from activity profile and energy cost of each activity*

(Mean values and standard deviations)

\begin{tabular}{|c|c|c|c|c|c|c|c|c|}
\hline \multirow[b]{2}{*}{ Activity } & \multirow{2}{*}{$\begin{array}{c}\text { No. of } \\
\text { observations }\end{array}$} & \multicolumn{3}{|c|}{ Energy cost (kJ/min) } & \multicolumn{3}{|c|}{ Energy cost (kJ/kg per min) } & \multirow{2}{*}{$\begin{array}{l}\text { Range of energy costs } \\
(\mathrm{kJ} / \mathrm{kg} \text { per } \mathrm{min})\end{array}$} \\
\hline & & Mean & SD & CV (\%) & Mean & SD & CV (\%) & \\
\hline \multicolumn{9}{|l|}{ Standard } \\
\hline Lying & 98 & $2 \cdot 940$ & 0.405 & 14 & 0.066 & 0.008 & 13 & $0.042-0.096$ \\
\hline Sitting & 98 & $3 \cdot 150$ & 0.468 & 15 & 0.075 & 0.012 & 17 & $0.071-0.075$ \\
\hline Standing & 98 & 3.430 & 1.196 & 35 & 0.079 & 0.016 & 21 & $0.075-0.079$ \\
\hline Walking & 85 & $8 \cdot 160$ & 1.698 & 21 & 0.188 & 0.025 & 13 & $0 \cdot 108-0.268$ \\
\hline \multicolumn{9}{|l|}{ Household } \\
\hline Cooking & 57 & $5 \cdot 770$ & 1.087 & 19 & 0.125 & 0.020 & 17 & $0.067-0.179$ \\
\hline Scouring vessels & 67 & 7.480 & 1.550 & 21 & 0.167 & 0.033 & 20 & $0.096-0.280$ \\
\hline $\begin{array}{l}\text { Arranging vessels } \\
\text { and folding beds }\end{array}$ & 44 & $9 \cdot 120$ & 1.535 & 17 & 0.205 & 0.029 & 14 & $0.105-0.259$ \\
\hline Sweeping & 74 & $9 \cdot 370$ & 0.470 & 21 & 0.217 & 0.038 & 17 & $0.125-0.292$ \\
\hline Washing clothes & 74 & $10 \cdot 210$ & 2.050 & 20 & 0.238 & 0.050 & 21 & $0.125-0.376$ \\
\hline Water-fetching & 51 & $12 \cdot 008$ & 2.430 & 20 & 0.280 & 0.054 & 19 & $0.142-0.376$ \\
\hline Mopping & 69 & $12 \cdot 510$ & 2.510 & 20 & 0.288 & 0.046 & 16 & $0.201-0.430$ \\
\hline \multicolumn{9}{|l|}{ Childcare } \\
\hline Standing holding child & 9 & 4.560 & 0.870 & 19 & 0.105 & 0.017 & 16 & $0.075-0.138$ \\
\hline Sitting with child & 7 & $5 \cdot 314$ & $1 \cdot 104$ & 21 & 0.138 & 0.033 & 24 & $0.096-0.188$ \\
\hline Bathing the child & 27 & $7 \cdot 866$ & 1.628 & 21 & $0 \cdot 188$ & 0.033 & 18 & $0.125-0.243$ \\
\hline Walking holding child & 11 & $9 \cdot 188$ & 1.757 & 19 & 0.213 & 0.025 & 12 & $0.163-2.615$ \\
\hline \multicolumn{9}{|l|}{ Occupational } \\
\hline Beedi-making & 34 & 4.393 & 0.669 & 15 & 0.092 & 0.013 & 14 & $0.067-0.121$ \\
\hline Sewing & 25 & 5.899 & $1 \cdot 280$ & 22 & $0 \cdot 125$ & 0.017 & 13 & $0.096-0.167$ \\
\hline Mean CV (\%) & & & & 23 & & & 20 & \\
\hline
\end{tabular}

\footnotetext{
${ }^{*}$ For details of procedures see p. 498.
} 
Table 3. Energy expenditure during each activity in terms of BMR multiples and their classification using World Health Organization/Food and Agriculture Organization/United Nations University (1985) criteria*

(Mean values and standard deviations)

\begin{tabular}{|c|c|c|c|c|c|}
\hline \multirow[b]{2}{*}{ Activity } & \multirow{2}{*}{$\begin{array}{c}\text { No. of } \\
\text { observations }\end{array}$} & \multicolumn{3}{|c|}{ Energy cost (kJ/min) } & \multirow{2}{*}{$\begin{array}{l}\text { Energy cost } \\
\text { BMR factor† }\end{array}$} \\
\hline & & Mean & SD & CV (\%) & \\
\hline \multicolumn{6}{|l|}{ Very light (<1.7 BMR) } \\
\hline Lying & 98 & 1.00 & & & 1.00 \\
\hline Sitting & 98 & 1.06 & 0.09 & 8.5 & 1.20 \\
\hline Standing & 98 & 1.14 & 0.12 & 10.5 & 1.50 \\
\hline Beedi-making & 34 & 1.50 & 0.04 & $2 \cdot 7$ & - \\
\hline Standing holding child & 9 & 1.63 & 0.30 & $18 \cdot 4$ & - \\
\hline \multicolumn{6}{|l|}{ Light (1·7-2.2 BMR) } \\
\hline Sitting with child & 7 & 1.90 & 0.30 & $16 \cdot 0$ & - \\
\hline Cooking & 57 & 1.97 & 0.39 & $20 \cdot 0$ & 1.80 \\
\hline Sewing & 25 & 2.07 & 0.44 & - & - \\
\hline \multicolumn{6}{|l|}{ Moderate (2.2-2.8 BMR) } \\
\hline Scouring vessels & 67 & 2.53 & 0.48 & $19 \cdot 0$ & - \\
\hline Bathing the child & 27 & $2 \cdot 67$ & 0.51 & $19 \cdot 0$ & - \\
\hline \multicolumn{6}{|l|}{ Heavy (>2.8 BMR) } \\
\hline Walking & 85 & $2 \cdot 80$ & 0.12 & 4.8 & 3.40 \\
\hline Arranging vessels and folding beds & 44 & 3.07 & 0.45 & $15 \cdot 0$ & - \\
\hline Walking holding the child & 11 & $3 \cdot 18$ & 0.64 & $20 \cdot 0$ & - \\
\hline Sweeping & 74 & 3.20 & 0.62 & $19 \cdot 4$ & 3.00 \\
\hline Washing clothes & 74 & 3.50 & 0.66 & $19 \cdot 0$ & 3.00 \\
\hline Water-fetching & 51 & $4 \cdot 10$ & 0.89 & $22 \cdot 0$ & - \\
\hline Mopping & 69 & $4 \cdot 25$ & 0.77 & $18 \cdot 0$ & - \\
\hline Mean CV (\%) & & & & $15 \cdot 5$ & \\
\hline
\end{tabular}

${ }^{*}$ For details of procedures see p. 498.

† World Health Organization/Food and Agriculture Organization/United Nations University (1985).

sample collection thus requiring more energy when compared with the energy expenditure during the activity of standing and holding the child.

Mean energy expenditures expressed in terms of BMR factors are given in Table 3 . They have been further divided into very light $(<1.7 \mathrm{BMR})$, light $(1.7-2.2 \mathrm{BMR})$, moderate $(2 \cdot 2-2 \cdot 8 \mathrm{BMR})$ and heavy $(>2.8 \mathrm{BMR})$, based on the World Health Organization/Food and Agriculture Organization/United Nations University (1985) criteria of classifying occupational activities. Most of the standard activities could be classified into the very light $(<1.7 \mathrm{BMR})$ category, the household activities into the heavy $(>2 \cdot 8 \mathrm{BMR})$ category and childcare activities into the moderate (2.2-2.8 BMR) category. It was of note that the occupational activities, i.e. beedi-making and tailoring were either very light (1.5 BMR) or light (2.07 BMR). Mopping was the heaviest among all the activities measured requiring around 4.25 BMR energy equivalents. Walking holding the child was the heaviest among the childcare activities ( $3 \cdot 18 \mathrm{BMR})$. The energy expenditure values in terms of BMR factors reported in the World Health Organization/Food and Agriculture Organization/United Nations University (1985) report are given for comparison. The CV decreased substantially when the energy cost values were expressed in terms of BMR factors.

The impact of long hours of women's work at the occupation on the energy cost of different activities is given in Table $4(\mathrm{~kJ} / \mathrm{min}$ and BMR factors). There were no differences in the energy equivalents for each of the activities in the three occupational groups except for water-fetching in the homemakers category for which the energy equivalent was significantly lower when compared with the beedimakers and tailors $(P<0 \cdot 05)$.

\section{Discussion}

This present study provides valuable information on the energy expenditure values of different household, childcare and some occupational activities of urban poor women from India. It also generates a database, which may be used to compute the energy requirements of women from similar backgrounds when their time-use patterns are available.

The mean weight and height of the study group were $43.6 \mathrm{~kg}$ and $1.504 \mathrm{~m}$, which were similar to the reported values for urban poor Indian women from ten states of India (National Nutrition Monitoring Bureau, 1994). Women tailors, however, were better nourished (mean weight $47.0 \mathrm{~kg}$, height $1.52 \mathrm{~m}$ ) (Table 1) when compared with the rest of the study group. The energy costs of standard activities including BMR were comparable with the published values from India (Durnin et al. 1990; Piers \& Shetty, 1993; Damayanthi, 1995). When the BMR factors were calculated, the results of the energy equivalents for the standard activities such as sitting and standing in this present study appear to be lower when compared with World Health Organization/Food and Agriculture Organization/United Nations University (1985) reported values. As stated earlier, these activities were measured when the subject was fasting.

Most of the available studies provide data on energy cost 
Table 4. Energy cost of activities of women of different occupations*

(Mean values)

\begin{tabular}{|c|c|c|c|c|c|c|c|c|c|}
\hline \multirow[b]{2}{*}{ Activities } & \multicolumn{3}{|c|}{ Homemakers } & \multicolumn{3}{|c|}{ Beedi-makers } & \multicolumn{3}{|c|}{ Tailors } \\
\hline & $\begin{array}{c}\text { No. of } \\
\text { observations }\end{array}$ & $\begin{array}{l}\text { Energy cost } \\
(\mathrm{kJ} / \mathrm{min})\end{array}$ & $\begin{array}{l}\text { BMR } \\
\text { factor }\end{array}$ & $\begin{array}{c}\text { No. of } \\
\text { observations }\end{array}$ & $\begin{array}{l}\text { Energy cost } \\
(\mathrm{kJ} / \mathrm{min})\end{array}$ & $\begin{array}{l}\text { BMR } \\
\text { factor }\end{array}$ & $\begin{array}{c}\text { No. of } \\
\text { observations }\end{array}$ & $\begin{array}{l}\text { Energy cost } \\
(\mathrm{kJ} / \mathrm{min})\end{array}$ & $\begin{array}{l}\text { BMR } \\
\text { factor }\end{array}$ \\
\hline \multicolumn{10}{|l|}{ Standard } \\
\hline Lying & 32 & 2.92 & 1.00 & 36 & 2.89 & 1.00 & 30 & 2.97 & 1.00 \\
\hline Sitting & 32 & 3.09 & 1.06 & 36 & 3.09 & 1.06 & 30 & $3 \cdot 18$ & 1.09 \\
\hline Standing & 32 & $3 \cdot 31$ & 1.13 & 36 & $3 \cdot 26$ & $1 \cdot 15$ & 30 & $3 \cdot 31$ & $1 \cdot 13$ \\
\hline Walking & 29 & $7 \cdot 87$ & 2.67 & 34 & $8 \cdot 20$ & $2 \cdot 82$ & 22 & 8.62 & 2.90 \\
\hline \multicolumn{10}{|l|}{ Household } \\
\hline Cooking & 19 & $5 \cdot 73$ & $1 \cdot 87$ & 27 & $5 \cdot 56$ & 1.95 & 11 & $6 \cdot 40$ & $2 \cdot 23$ \\
\hline Scouring vessels & 24 & $7 \cdot 28$ & 2.44 & 31 & 7.57 & 2.59 & 12 & 7.57 & 2.52 \\
\hline $\begin{array}{l}\text { Arranging vessels and } \\
\text { folding beds }\end{array}$ & 15 & $9 \cdot 16$ & 3.01 & 19 & $8 \cdot 83$ & 3.07 & 10 & 9.54 & 3.17 \\
\hline Sweeping & 26 & $9 \cdot 16$ & 3.09 & 32 & 9.25 & 3.22 & 16 & 9.87 & 3.35 \\
\hline Washing clothes & 26 & $10 \cdot 12$ & 3.43 & 32 & $10 \cdot 17$ & 3.54 & 16 & $10 \cdot 42$ & 3.52 \\
\hline Water-fetching & 20 & 11.29 & $3.76^{\mathrm{a}}$ & 20 & 12.47 & $4.40^{b}$ & 11 & $12 \cdot 38$ & $4 \cdot 17^{\mathrm{c}}$ \\
\hline Mopping & 26 & 11.88 & 3.90 & 30 & $12 \cdot 84$ & 4.49 & 16 & $13 \cdot 14$ & 4.40 \\
\hline \multicolumn{10}{|l|}{ Occupational } \\
\hline Beedi-making & & - & - & 34 & 4.35 & 1.50 & & - & - \\
\hline Sewing & & - & - & & - & - & 25 & $6 \cdot 15$ & 2.07 \\
\hline
\end{tabular}

${ }^{a, b}$ Mean values within a row with unlike superscript letters were significantly different $(P<0.05)$.

${ }^{*}$ For details of procedures see p. 498.

of sports, occupational and recreational activities (Williams, 1976; William et al. 1981; Bouchard et al. 1983). Published studies from developing countries provide information on the energy cost of agricultural activities and a few household and standard activities (Banerjee et al. 1971; Deguzman et al. 1974; Montgomery \& Johnson, 1977; Benjamin et al. 1982). Passmore \& Durnin (1955) as long ago as 1955 published data on the energy expenditure of household activities from the Western world. World Health Organization/Food and Agriculture Organization/United Nations University (1985) and Ainsworth et al. (1993) collated data from published studies on the energy cost of activities including sports, recreation, occupation and home-based activities etc. in terms of BMR and metabolic equivalent units. These included both measured and derived values. Ainsworth et al. (1993) arrived at a compendium which is a unique coding system that classifies the energy cost of physical activities by grouping them based on their type and intensity for uniform use in clinical settings, physical activity research and education.

It is interesting to note that the present study reports the results of energy expenditure of a large number of activities unique to the work patterns in India and classified under housework and childcare. In the case of a few activities reported here, it was found that there were no differences between the values of this study when compared with other studies from developing countries (Banerjee et al. 1971; Deguzman et al. 1974; Montgomery \& Johnson, 1977; Benjamin et al. 1982). It was discovered that a few predominant activities measured in this study corresponded to the description of activities from a Guatemalan study, where women did not have access to mechanical appliances at home (Benjamin et al. 1982). Differences in the remainder may be explained by the small sample sizes, different work patterns and differing methodologies. The number of activities and the sample size of the present study were much larger when compared with the available published work.

It was observed that most of the household activities except scouring vessels and cooking may be classified into the heavy category based on World Health Organization/ Food and Agriculture Organization/United Nations University (1985) classification (Table 3); however, the Guatemalan study, using the Food and Agriculture Organization/World Health Organization (1973) classification suggested that household activities lie between sedentary and moderate (Benjamin et al. 1982).

When the results of this present study were compared with the compendium of Ainsworth et al. (1993) it was found that the values of the present study were in the range of the values coded for home activities of the compendium (range of present study values were 1.5-4.25 BMR v. 1.55.5 metabolic equivalents of the compendium). The differences could be accounted for by the differences in grouping of the activities (e.g. energy expenditure for bathing the child was 2.67 BMR in the present study, whereas it was 3.0 metabolic equivalents for childcare in the compendium which included feeding and lifting the child along with bathing the child).

The CV decreased significantly when the energy cost values were expressed as $\mathrm{kJ} / \mathrm{kg}$ body weight per min rather than $\mathrm{kJ} / \mathrm{min}$ (Table 2). When energy expenditure costs of activities were expressed as BMR units, the variation further decreased (CV 15.5\%) (Table 3).

The occupational status of the women did not affect the energy expended on the various activities both in terms of $\mathrm{kJ} / \mathrm{min}$ and BMR units, except in the case of water-fetching, where homemakers spent less energy in terms of BMR units than the other two groups $(P<0.05)$. However, homemakers 
appear to spend less energy in terms of $\mathrm{kJ} / \mathrm{min}$ when compared with beedi-makers and tailors in most of the instances, though the differences are not significant. The 4-6h occupational work squatting on the floor appears to reduce the efficiency of beedi-makers and tailors while performing the heavy household and childcare activities in the upright posture.

Therefore, this study generates a database for energy cost of activities of women from the low socio-economic group of three occupational groups from urban India. It may be utilized to calculate the energy expenditures and arrive at energy requirements of women. However, similar studies in the other occupational groups need to be carried out.

\section{Acknowledgements}

The authors are grateful to Dr Kamala Krishnaswamy, Director, National Institute of Nutrition, Hyderabad, for encouragement during the study. The help rendered by Ms K. Usha Rani, Ms K. S. Padmavathi, Ms A. Padma Siromani, Mr G. V. Narsimha Rao, Mr G. Chenna Krishna Reddy, Mr Sudhakar and Dr R. Subramanian is gratefully acknowledged. The authors are thankful to the slum women for their cooperation throughout the study.

\section{References}

Ainsworth BE, Haskell WL, Leon AS, Jacobs DR, Montoye HJ, Sallis JF \& Paffenbarger RS (1993) Compendium of physical activities: classification of energy costs of human physical activities. Medicine and Science in Sports and Exercise 25, 71-80.

Banerjee B, Khew KS \& Saha N (1971) A comparative study of energy expenditure in some common daily activities of nonpregnant and pregnant Chinese, Malay and Indian women. Journal of Obstetrics and Gynecology 78, 113-116.

Banerjee S (1962) Studies on Energy Metabolism, Indian Council of Medical Research Special Report Group no. 43. New Delhi: ICMR.

Batliwala S (1985) Women in poverty: The energy, health and nutrition syndrome. In Tyranny of the Household, pp. 38-50 [D Jain and N Banerjee, editors]. New Delhi: Modern Printers.

Benjamin T, McGuire J \& Mendoza RD (1982) Energy cost of activities and tasks of women from a rural region of Guatemala. Nutrition Research 2, 127-136.

Bouchard C, Tremblay A, Leblanc C, Lortie G, Savard R \& Theriault G (1983) A method to assess energy expenditure in children and adults. American Journal of Clinical Nutrition 37, 461-467.

Dakshayani R, Ramanamurthy PSV \& Srikantia SG (1962) Body composition and basal metabolism of normal Indian women. Indian Journal of Medical Research 50, 800-803.

Damayanthi K (1995) Energy cost of pregnancy in rural Indian women. PhD Thesis, SNDT Women's University, Bombay.

Deguzman MPE, Domiugnez SD, Kalaw JM, Buning MN, Basconcillo RO \& Santos VF (1974) A study of the energy expenditure, dietary intake and pattern of daily activity among various occupational groups II. Markina shoemakers and housewives. Philippine Journal of Nutrition 27, 21-30.

Douglas CG (1911) A method for determining the total respiratory exchange in man. Journal of Physiology 42, 17-18.

Durnin JVGA, Drummond S \& Satyanarayana K (1990) A collaborative EEC study on seasonality and marginal nutrition. The Glasgow-Hyderabad (S. India) study. European Journal of Clinical Nutrition, Suppl. 1, 19-29.
Food and Agriculture Organization/World Health Organization (1973) Report of a Joint Expert Consultation. Energy and Protein Requirements. World Health Organization Technical Report Series no. 524. Geneva: WHO.

Gopalan C, Srikantia SG \& Venakatachalam PS (1955) Body composition and basal metabolism of normal subjects. Journal of Applied Physiology 8, 142-144.

Indian Council of Medical Research (1989) Report of the Expert Group: Nutrient Requirements and Recommended Dietary Allowances for Indians. New Delhi: ICMR.

Jeffery P, Jeffery R \& Lyon A (1989) Labour Pains and Labour Power. Women Child Bearing in India. New Delhi: Manohar Publishers.

Khan L \& Belvady B (1973) Basal metabolism in pregnant and nursing women and children. Indian Journal of Medical Research 61, 1-8.

McNeill G, Rivers JPW, Payne PR, de Britto JJ \& Abel R (1987) Basal metabolic rate of Indian men: No evidence of metabolic adaptation to a low plane of nutrition. Human Nutrition: Clinical Nutrition 41C, 473-483.

Montgomery E \& Johnson A (1977) Michiguenga energy expenditure. Ecology of Food and Nutrition 6, 97-105.

National Nutrition Monitoring Bureau (1994) Urban Survey. Hyderabad: National Institute of Nutrition.

Passmore R \& Durnin JVGA (1955) Human energy expenditure. Physiological Reviews 35, 801-840.

Piers LS \& Shetty PS (1993) Basal metabolic rates of Indian women. European Journal of Clinical Nutrition 47, 587-591.

Ramanamurthy PSV \& Dakshayani R (1962) Energy intake and expenditure in stone cutters. Indian Journal of Medical Research 50, 804-809.

Shatrugna V, Vidyasagar P, Sujatha T \& Vasanthi G (1993) The Women's Work and its Impact on Child Health and Nutrition. Hyderabad: National Institute of Nutrition.

Shetty PS (1984) Adaptive changes in basal metabolic rate and lean body mass in chronic undernutrition. Human Nutrition: Clinical Nutrition 38C, 443-451.

Venkatachalam PS, Srikantia SG \& Gopalan C (1954) Basal metabolism in nutritional edema. Metabolism 3, 138-141.

Viteri FE, Torun B, Galicia JC \& Herrera E (1971) Determining the energy costs of agricultural activities by respirometer and energy balance techniques. American Journal of Clinical Nutrition 24, 1418-1430.

Weir J (1949) New methods for calculating metabolic rate with special reference to predicting protein metabolism. Journal of Physiology 109, 1-9.

Williams MH (1976) Nutritional aspects of human physical and athletic performance, pp. 30-42. Springfield, IL: Charles C. Thomas.

William DM, Frank IK \& Victor LK (1981) Energy Expenditure in Household, Recreational and Sports Activities. Appendix D, Exercise Physiology, pp. 486-493. Philadelphia, PA: Lea \& Febiger.

World Health Organization/Food and Agriculture Organization/ United Nations University (1985) Report of a Joint Expert Consultation: Energy and Protein Requirements. Technical Report Series no. 724. Geneva: WHO.

\section{Appendix \\ Description of typical activity measurements}

1. Sitting and standing. Energy expenditure for sitting and standing activities were measured using the KofranyiMichaelis meter described on p. 498. The usual time for the collection of the sample of expired air was $6 \mathrm{~min}$. 
2. Walking. Each subject was required to walk at her normal pace (this was confirmed from the observation notes) during the period of sample collection.

3. Sweeping. This activity was carried out with the subject walking forward holding a broom in a partially flexed posture. The broom was about $0.5 \mathrm{~m}$ long and the subject was required to sweep the floor, uniformly sprinkled with sawdust.

4. Mopping the floor. This activity was carried out with the help of a wet rag of standard size. The women moved backwards on their haunches as they mopped a standard area, and the sample of expired air was collected only for 5 min.

5. Scouring vessels. Sitting on a small stool, the women were required to bend forward as they scoured and washed their pots, pans, plates, tumblers, spoons etc.

6. Washing clothes. The first part of this activity was largely carried out in a sitting and flexed posture. Subjects washed six to eight garments belonging to their family. The activity included applying soap, scrubbing the cloth against the floor with vigorous movements, followed by rinsing each garment twice in a bucket of water. The clothes were then squeezed dry by wringing them. The rinsing and wringing were done in a standing and bent posture.

7. Water-fetching. Women carried the empty pot to the common public tap about $10 \mathrm{~m}$ away and waited in a queue for about 30-60 s, while the pot was being filled, and carried it back to their homes on their hips. The water was poured out into a storage drum in the kitchen and the empty pot carried back to the tap. Women collected three to four pots of water during the time necessary for sample collection.

8. Cooking. This activity was usually carried out in a sitting posture in front of a stove. The activities included: measuring out the rice into a large vessel, washing it two or three times, draining the water, and placing the vessel on the stove after adding the measured amount of water. As women watched the rice boil, they cut and washed vegetables, cleaned the area, and threw the peels in the dustbin. They had to stir the boiling rice five to six times before it was cooked. Postures during this activity involved sitting on the floor, rising from the floor and walking around the kitchen at least twice. The women were not disturbed during this activity, so the duration of the sample collection was determined by the cooking time of the rice, which was usually $15-20 \mathrm{~min}$.

9. Arranging the utensils and clearing the beds. The subject was required to arrange the washed kitchen utensils such as plates, glasses, cups and spoons on a rack, placing them in two rows. The rack was $0.5 \mathrm{~m}$ from the ground. In addition, the children's bedding was cleared, the blankets and sheets folded and put away on a rack $1 \mathrm{~m}$ from the ground. This work involved walking around in a room, bending, standing and reaching out to place the things on the rack.
10. Bathing and dressing the child. There were twentyseven women with small children and this activity was measured in all of them. However, the other childcare activities were measured in a smaller number of women. Women carried the warm water to the bathroom, mixed it with the cold water to the required temperature, undressed and bathed the child with soap and water. After this, the child was dried with the towel, led out of the bathroom and dressed. At the same time, mothers completed the chore of dabbing some powder on the child's face, combing the hair and applying a red spot on the forehead in the case of a girl. The postures in which this activity was carried out required the women to move around as they bent forward most of the time.

11. Sitting, holding the child. Seven women, whose activity profiles included this activity were considered for this measurement. Women were required to hold the child on their laps and the expired air was collected. The child was awake and active with vigorous movements, and the mother had to exert herself to control the child on her lap.

12. Standing, holding the child. Women were asked to hold the child during the sample collection. The child was held comfortably against the shoulder of the mother and facing the opposite direction. Usually the children did not move as the sample of expired air was collected.

13. Walking with the child. In this particular activity, women walked at their usual pace carrying the children on their hips.

14. Beedi-making. The subjects sat on the floor, with the tobacco, the leaves and the thread arranged on a tray. A pinch of tobacco was first placed in the leaf, and it was rolled into a $30-40 \mathrm{~mm}$ long conical shaped beedi. The narrow end was tied with a piece of thread to prevent the tobacco from slipping out, and the other end tucked in with the tip of the finger. The normal rate of rolling the beedies was usually $4-5$ per min. All the women worked at this pace during the sample collection.

15. Sewing. Women tailors sat on small stools (about $1 \mathrm{~m}$ in height) in front of their sewing machines. They worked with their feet on a pedal, controlling the speed of the machine with the physical force that they applied on the pedal. Women sewed their customer's garments while the sample of expired air was collected. In a sub-sample of three women the results were confirmed by the collection of the expired air for the whole duration of stitching a blouse.

The BMR and the energy cost of sitting and standing were measured in the fasting state. All the other measurements were carried out in the postprandial state. Based on the observational pattern, about sixteen measurements were thus carried out in the majority of the women. 